\title{
UPGRADING MANUAL TURNING MACHINE TOWARDS IoT-BASED MANUFACTURING
}

\author{
Sutopo $^{1}$, Bayu Rahmat Setiadi ${ }^{1}$ and Muhammad Hanzla ${ }^{2}$ \\ ${ }^{1}$ Department of Mechanical Engineering Education, Universitas Negeri Yogyakarta, Yogyakarta, Indonesia \\ ${ }^{2}$ Institute of Aviation Studies (IAS) University of Management and Technology (UMT), Lahore, Punjab, Pakistan \\ E-mail: sutopo@uny.ac.id
}

\begin{abstract}
Technological independence is one aspect of the challenges of the industrial revolution era 4.0. Digitalization, robotization, big data, internet of things (IoT), and efficiency of work processes require an update in technology. If everything is held in the fulfillment of practicum facilities, it will undoubtedly cost a prohibitive fee. Many of the tools and machines found in learning machining practices in Vocational High Schools (VHS) in Indonesia are still a conventional machine. This study provides a breakthrough solution in the effectiveness and efficiency of traditional machining of the lathe that starts with a preliminary identification of literature, selection according to inclusion and exclusion criteria, coding, themes classifications, and supplementary areas. Through the literature review methodology, this article has the main objective of identifying the needs in architecture and the need for supporting devices on conventional lathes based on the IoT as well as safe, comfortable, and modern work areas in lathe machining practices.
\end{abstract}

Keywords: conventional machine upgrading, IoT-based turning machine, technology independence

\section{INTRODUCTION}

The industrial revolution has four developments, namely the 1.0 industrial revolution in 1776 with mechanization, the 2.0 industrial revolution in 1913 with mass production, the 3.0 industrial revolution in 1990 with automation, and the industrial revolution in 2011 with cyber-physical systems. The Industrial Revolution 4.0 was first promoted when the 2011 Hannover Fair was held in Germany [1], [2]. Initiation Germany introduces the Fourth Industrial Revolution (4IR) is a policy to realize development plans through the High-Tech Strategy 2020. Germany has predicted an increase in manufacturing efficiency from $6 \%$ to $8 \%$ by applying the industrial revolution 4.0 to the global economic [3].

The industrial revolution had a significant impact on economic growth and the modernization of systems in various countries. The presence of IR 4.0 has a significant effect on labor reduction because the production system moves in an automated and remote work system. Some of the fields of IR 4.0 include implantable technologies, our digital presence; vision as the new interface, wearable internet, ubiquitous computing, supercomputer in your pocket, storage for all, the internet of and for things, the connected home, smart cities, big data for decisions, driverless cars, artificial intelligence and decision-making, AI and white-collar jobs, robotics and services, bitcoin and the blockchain, the sharing economy, governments, and the blockchain, 3D printing and manufacturing, 3D printing and human health, 3D printing and consumer products [4].

Indonesia is entering a new phase in the progress of science and technology. The Ministry of Industry of the Republic of Indonesia initiated a policy of prioritizing five main sectors such as automotive, textiles, food and beverages, electronics, and chemicals [5]. The industrial revolution benefits users and workers, but it also 
provides shortcomings to the enormous dependence on technology [3]. IR 4.0 has a significant impact on economic growth and system modernization in various countries.

The development of the industrial revolution began to spread to education. Education in Indonesia has already started to improve its systems and facilities towards 4.0 [6]. Through the Directorate of Vocational High School Development (DVHSD), the modernization of vocational workshops began to be prepared to adjust the demands of the workforce oriented 4.0 [7]. According to Charles A. Prosser, vocational education will be useful if facilities, tools, work culture, instructors, competencies, and financing must be by the conditions of the world of work [8]. he information shows that the concurrency between what is in VHS is industrial replication, so it can be said to be a small industry. Therefore, vocational schools in the IR 4.0 era need to upgrade their facilities to facility 4.0.

Vocational high schools are formal education disrupted by the industrial revolution 4.0. The phenomenon that occurs at this time is learning that has not followed the current century. The DVHSD complained that school infrastructure is currently the same as the 19th Century, human resources supporting education are still the same as the 20th Century [9], while students and job opportunities faced today are in the 21st Century [10]. The existence of these problems can be addressed by improving existing facilities by replacing work systems or upgrade facilities to additional functions that are more sophisticated and modern.

One of the expertise competencies in VHS affected by IR 4.0 is mechanical engineering. The main facilities in the field are workshops and laboratories. The workshop consists of five main aspects that need to be managed, including tools or machines, materials, human resources, learning, and work area layout [11]. A suitable machining workshop is modern, safe, comfortable, healthy, and safe [12]. It means that schools need to revitalize vocational workshops on these elements following IR 4.0. There is a need for connectivity devices in conventional turning through upgrading the system to be integrated, interconnected, digital, internet of things, and cloud-based manufacturing [13], [14]. One modification that needs to be the object of Cloud-based Manufacturing experiments is lathe machining. The conventional machining needs to be upgraded to a machine by the demands of the IR 4.0. By aligning the machining workshop model by IR 4.0, the requirements and needs of students and stakeholders are linear.

This study aims to develop conventional cloud-based machining devices as a form of independence of school technology without providing new tools or machines. The existence of this research is expected to provide concrete steps in solving the problem of upgrading conventional machines into manufacturing 4.0.

\section{METHOD}

The study methods used in upgrading conventional lathes refer to the five steps in the synthesis of theories which include: (1) preliminary identification of literature; (2) Selection according to inclusion and exclusion criteria; (3) coding, (4) themes classifications; and (5) supplementary areas. In more detail, this study is explained in the conceptual stages presented in Figure 1.

The use of the literature method is a roadmap of the researchers, especially in introducing new concepts in the renewal of conventional machines owned by VHS. Modification and development of tools and 
devices are the results of studies that can be accounted for by the public. Adoption of the existing manufacturing IoT-based CNC [15] then developed and adapted to the conditions of the tools and machines in VHS.
Conceptual testing is carried out through expert validation conducted by VHS teachers of St. Mikael Solo and machining practice experts from Yogyakarta State University.

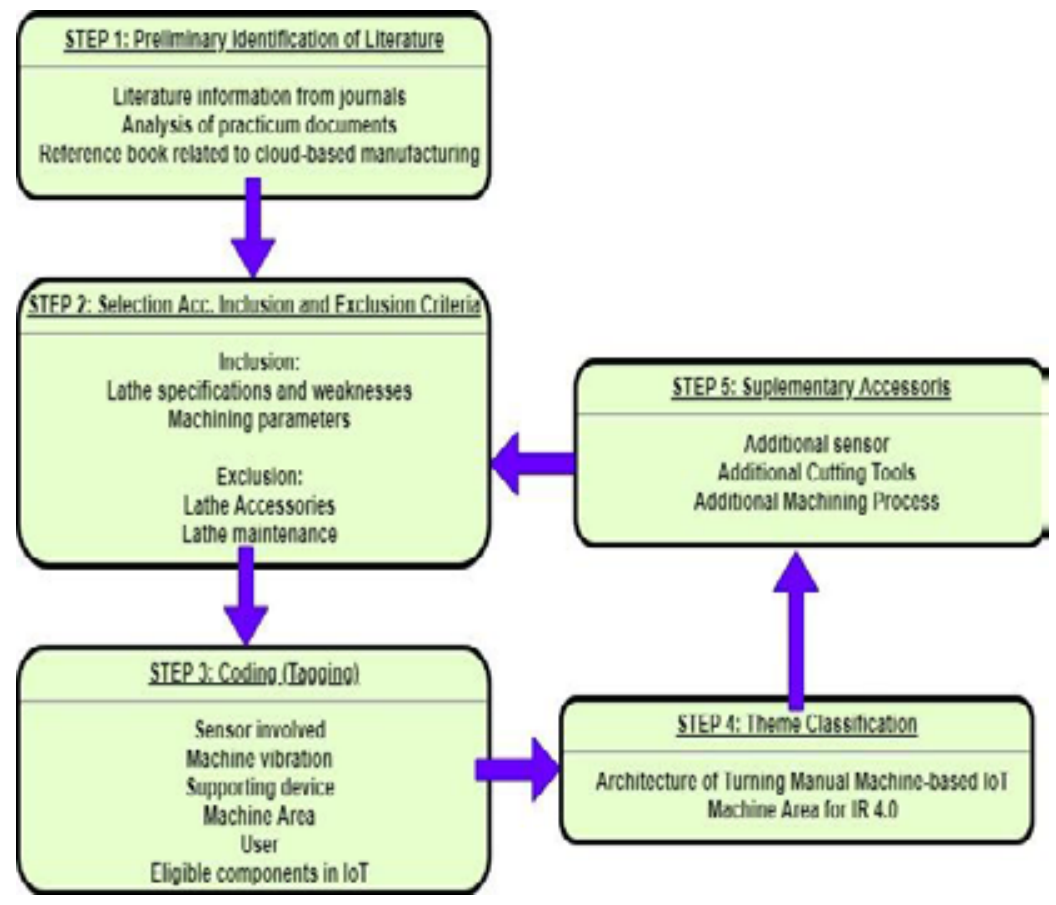

Figure 1. The Methodology of the Literature Review

The Focus Group Discussion (FGD) gave rise to the term technological independence for VHS, which has limited facilities and infrastructure to conduct new tools but by upgrading components based on IoT.

\section{RESULTS AND DISCUSSION}

The selection of competency expertise in the field of machining engineering, especially lathes, is very close to industrial modernization, so it needs a prototype [7] and IoT Architecture [16]. Machining jobs in the manufacturing industry nowadays have used a lot of non-conventional machines compared to vocational schools with tools or machines still included in the current category. According to Regulation of the Minister of

Education and Culture No. 8 of 2018 concerning Physical Allocation Funds (PAF) in the Field of Education, that for the working area of conventional lathes is $3 \times 3$ meters. If it is related to the conditions and needs of the students at this time, then a traditional machine can be said to be comfortable and safe when loading ergonomic checkpoints [17] and secure the function of disaster mitigation. The $21^{\text {st }}$ Century learning that demands on i-spaces and a free discussion vehicle in conventional lathes are an additional room accessory that needs to be considered [18]. In general, the initial conditions of the work area in the practice of 
twill find the following machines. Table 1 presents the Conventional Lathe Machine
Work Area Equipment in Modern Workshop of Vocational High School (VHS).

Table 1. Conventional Lathe Machine Work Area Equipment in Modern Workshop VHS [19]

\begin{tabular}{|c|c|c|c|c|c|}
\hline No. & Tools & Function & Qty & \pm Work Area $\left(\mathrm{m}^{2}\right)$ & Total $\left(\mathrm{m}^{2}\right)$ \\
\hline 1. & $\begin{array}{l}\text { Power Hacksaw } \\
\text { Machine }\end{array}$ & $\begin{array}{l}\text { To cut a large workpiece into small } \\
\text { parts before turning. }\end{array}$ & 2 & 1 & 2 \\
\hline 2. & Turning Machine & $\begin{array}{l}\text { For turning metal workpieces as } \\
\text { desired, with a maximum length of } 1 \\
\text { meter. }\end{array}$ & 16 & 6 & 96 \\
\hline 3. & $\begin{array}{l}\text { Shank Turning } \\
\text { Tool }\end{array}$ & $\begin{array}{l}\text { To cut a workpiece that is turned and } \\
\text { mounted on a lathe. }\end{array}$ & 16 & - & 0 \\
\hline 4. & Insert & Milling cutter. & 8 & - & 0 \\
\hline 5. & $\begin{array}{l}\text { CNC Lathe } \\
\text { Machine }\end{array}$ & $\begin{array}{l}\text { To turn the workpiece using a computer } \\
\text { program CNC-controlled lathe } \\
\text { machine. }\end{array}$ & 6 & 6 & 36 \\
\hline 6. & CNC Lathe Trainer & $\begin{array}{l}\text { The training on using a CNC lathe is } \\
\text { the same as the original, and the results } \\
\text { can be applied directly. }\end{array}$ & 6 & 6 & 36 \\
\hline
\end{tabular}

Expectations and desires of DVHSD regarding the ideal size of the work area need to be upgraded through the independence of school technology. This independence raises the spirit of schools to personally make efforts to enhance technology to catch up with the workforce needs that are increasingly pressing but not in line with industry expectations. The bridging of $21 \mathrm{st}$ Century skills and IR 4.0 encouraged schools to develop their machines to be complete, modern, and digital without having to go through a new procurement process [9]. Things like this are expected from the central government that schools need to do a renewable machine through empowering school capabilities. One of the ideas in this study is how to develop a conventional lathe into cloud manufacturing-oriented.

The study of CNC development, combined with IoT, is becoming viral in the advanced machining world [20], [21]. The rapid growth of technology certainly does not shift the existing function. Sophisticated modification of tools and machines was made to achieve a degree of effectiveness and efficiency in the manufacturing process.
Studies conducted by Zhong et al. show that there is a need for the direction of change not just to hold new facilities continuously but to update existing components by upgrading according to the conditions and issues that are developing at that time. The results of efficiency with this method are quite high compared to having to hold expensive new goods that are difficult to get [22].

Based on the description Table 1, it can be determined how the needs of the IoT architecture for the design of modern conventional lathes. The need for supporting components provides benefits in completing work functions in other parts. Various features are added to provide security, safety, easy access, and work efficiency both when working or when monitoring results. The following is a series of conventional IoTbased lathe architectures. The design of the lathe co-opted the accessories in $\mathrm{CNC}$ by adding some more modern features that can be accessed remotely. The devices needed in the modification of conventional IoT-based turning machines are presented in Figure 2, Table 2 and Figure 3. 


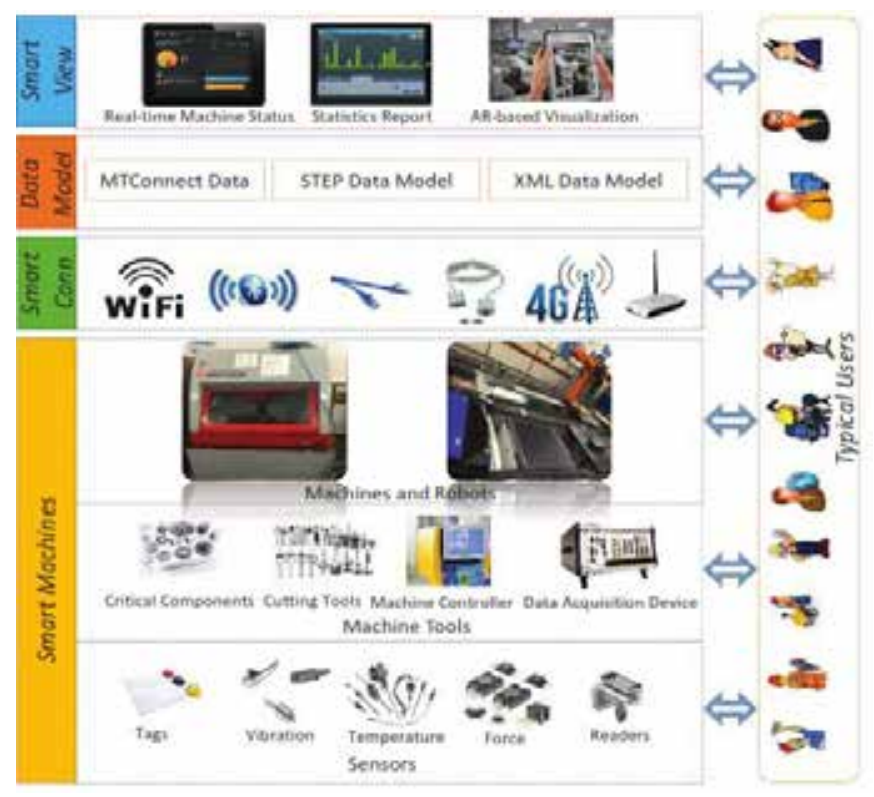

Figure 2. IoT in CNC Machine [15]

Table 2. IoT-based Conventional Lathe Accessories

\begin{tabular}{lll}
\hline Part & Type & Function \\
\hline $\begin{array}{l}\text { Touch temperature } \\
\text { sensor }\end{array}$ & MLX90614 & Measuring the temperature of the tool in the cutting process \\
$\begin{array}{l}\text { Motion sensor } \\
\text { Proximity Sensor }\end{array}$ & $\begin{array}{l}\text { Tachometer } \\
\text { Ultrasonic HC-SR04 }\end{array}$ & $\begin{array}{l}\text { Measuring the rotational speed of a spindle } \\
\text { Measuring movement above and transverse sled and automatic } \\
\text { functions }\end{array}$ \\
CCTV & $\begin{array}{l}\text { Hidden Cam } \\
\text { Vibration }\end{array}$ & $\begin{array}{l}\text { Observe turning and grading processes } \\
\text { Vibration }\end{array}$ \\
Digital Information & Realtime Monitoring & Monitor machine status, statistical reports, visualizations \\
\hline
\end{tabular}

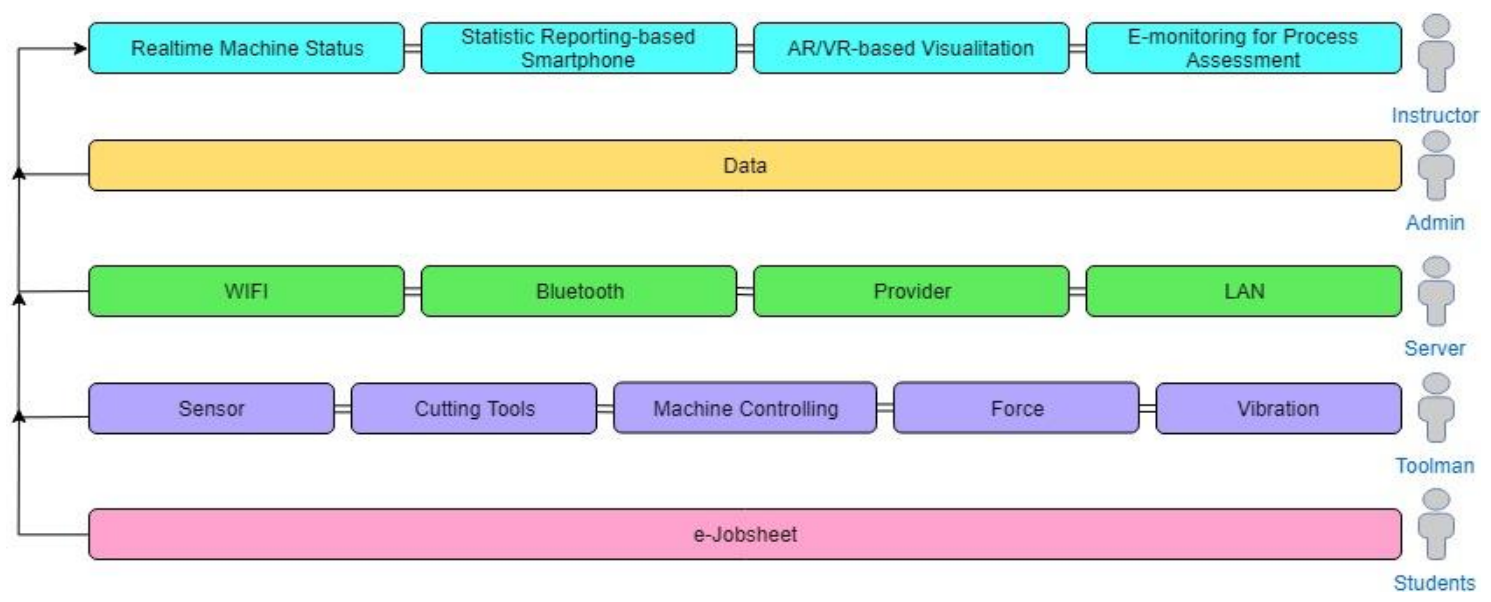

Figure 3. IoT-based Conventional Lathe Architecture

The design of the right workspace for learning conventional lathe needs to be adapted to the needs of today's millennial students. The need for digitalization not 
forgetting occupational safety and health is a priority in the design of this study. The digitization and the addition of several automatic sensors in several engine components can help in increasing the efficiency and effectiveness of work, especially in modernization and sophistication in the practice process. Besides, safe and beautiful layouts provide increased motivation for student practicum to be improved with the flexibility of accessible work areas. They are presented in Figure 4 and Figure 5.

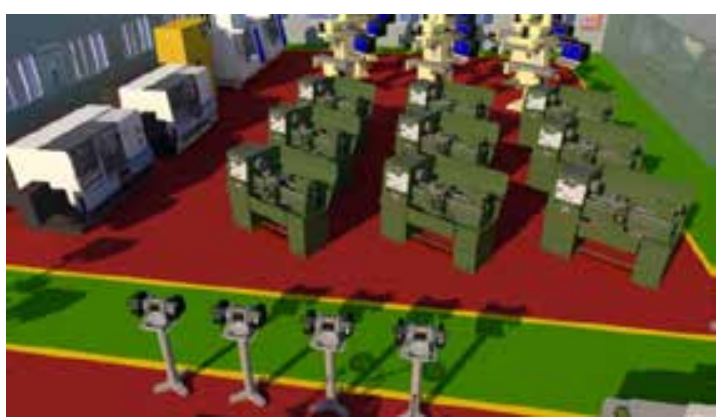

Figure 4. Illustration of Lathe Machine Work Areas with Modern, Comfortable and Safe Aspects

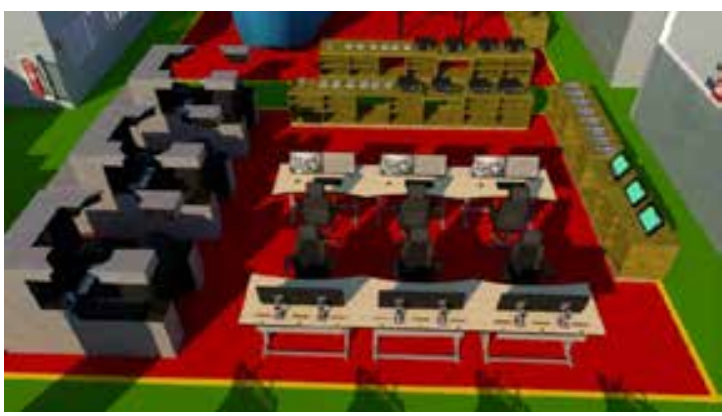

Figure 5. Illustration of Lathe Machine Work Areas with Complete Digitalization Visualization

The work area by ensuring ergonomic checkpoints in conventional lathe practices is vital in this study. The addition of work areas in the form of a set of computers, internet, and smartphones in the work area can support vocational learning 4.0. Learning continues to prioritize hands-on by combining practical skills and augmented reality into a balanced composition, especially in shaping competencies in the era of the industrial revolution 4.0.

\section{CONCLUSION}

A literature review provides new insights for researchers and readers that holding something new is expensive compared to modifying it. Outdated tools and machines affect costly and outdated machine maintenance and repairs. We need renewable devices so that they become younger and following the characteristics of today's millennial learners. The use of IoT as integrated digitization of learning seems to be preferred by students rather than operating conventional or manual machines. The renewal of the lathe with a robust 4.0 architecture can show the school has excellent technological independence. Recommendations suggested in this study are however the conditions and difficulties of facilities and infrastructure in vocational learning 4.0 can be addressed by managers through upgrading old machines into new machines with modifications between digital devices, sensors, devices, and other devices that support the era of the industrial revolution 4.0.

\section{REFERENCES}

[1] V. Roblek, M. Meško, and A. Krapež, "A Complex View of Industry 4.0," SAGE Open, vol. 6, no. 2, 2016.

[2] A. Rojko, "Industry 4.0 Concept: Background and Overview," Int. J. Interact. Mob. Technol., vol. 11, no. 5, pp. 77-90, 2017.

[3] Y. Liao, E. R. Loures, F. Deschamps, G. Brezinski, and A. Venâncio, "The impact of the fourth industrial revolution: a cross- 
country/region comparison," Production, vol. 28 , no. 0 , pp. 1-18, 2018 . K. Schwab, The Fourth Industrial Revolution. Geneva: World Economic Forum, 2016.

[5] A. Haupt and A. Lerch, "Forward osmosis application in manufacturing industries: A short review," Membranes (Basel)., vol. 8, no. 3, 2018 .

[6] B. R. Setiadi, S. Setuju, D. Ratnawati, S. Suparmin, S. Sugiyono, and A. Widatmoko, "E-monitoring in the vocational process-based assessment," Int. J. Eng. Technol., vol. 7, 2018.

[7] C. A. Lauff, D. Kotys-Schwartz, and M. E. Rentschler, "What is a prototype? what are the roles of prototypes in companies?," J. Mech. Des. Trans. $A S M E$, vol. 140, no. 6, 2018.

[8] P. Sudira, "Indonesia vocational education praxis betwen," in Empowering Vocational Education and Training to Elevate National Economic Growth, 2014, pp. 190-200.

[9] T. Suartini, "Influence Application of Learning Model on Vocational Education Based on Quality Issurance," $S A G E$ Open, vol. 9, no. 2, 2019.

[10] J. Holstead and M. H. King, "HighQuality 21st Century Community Learning Centers: Academic Achievement Among Frequent Participants and Non-Participants," $J$. Educ. Students Placed Risk, vol. 16, no. 4, pp. 255-274, 2011.

[11] H. Abdul Zubar, K. Visagavel, V. Deepak Raja, and A. Mohan, "Occupational health and safety management in manufacturing industries," $J$. Sci. Ind. Res. (India)., vol. 73, no. 6, pp. 381-386, 2014.

[12] V. O. Iwaifo, "Better be safe than be sorry: An analysis of workshop \nbehaviour in vocational and technical schools," Int. NGO J., vol. 4, no. 9, pp. 386-390, 2009.

[13] A. S. Reddy, B. Jaya, and N. Satish, "Review on Real Time Control of Lathe
Machine During Turning Operations," Int. J. Tech. Innov. Mod. Eng. Sci., vol. 5, no. 4, pp. 826-832, 2019.

[14] P. N. Parmar, V. R. Gondalia, N. C. Mehta, M. E. Scholar, and A. Professor, "Review on Advance Automation of Conventional Lathe Machine," Int. J. Eng. Dev. Res., vol. 2, no. 2, pp. 23219939, 2014.

[15] R. Y. Zhong, L. Wang, and X. Xu, “An IoT-enabled Real-time Machine Status Monitoring Approach for Cloud Manufacturing," Procedia CIRP, vol. 63, pp. 709-714, 2017.

[16] M. Saqlain, M. Piao, Y. Shim, and J. Y. Lee, "Framework of an IoT-based Industrial Data Management for Smart Manufacturing," J. Sens. Actuator Networks, vol. 8, no. 2, 2019.

[17] ILO, Ergonomic checkpoints: Practical and easy-to-implement solutions for improving safety, health and working conditions, Second Edi., vol. 91. Geneva: ILO publications, 2010.

[18] J. Gendall, "21st-Century Newsroom Design," Pro $A V$, vol. 25, no. 3, p. 15, 2008.

[19] K. I. Ismara, B. R. Setiadi, A. W. Khurniawan, and D. Supriadi, "Rearranging laboratory design towards good vocational school governance," $J$. Adv. Res. Dyn. Control Syst., vol. 11, no. 12 Special Issue, pp. 301-305, 2019.

[20] P. Zheng et al., "Smart manufacturing systems for Industry 4.0: Conceptual framework, scenarios, and future perspectives," Front. Mech. Eng., vol. 13, no. 2, pp. 137-150, 2018.

[21] A. K. Nandi, "Design \& Implementation of an IoT Based 3-Axis CNC VMC," Int. J. Sci. Eng. Res., vol. 9, no. 6, pp. 145152, 2018.

[22] B. R. Setiadi, S. Setuju, T. Sukardi, and S. Sugiyono, "Efficiency of material consumption in sustainable conventional machining practices," IOP Conf. Ser. Mater. Sci. Eng., vol. 434, p. 012175, 2018. 